\title{
Formation of Enzymes of Autotrophic Metabolism During Heterotrophic Growth of Alcaligenes eutrophus
}

\author{
By CORNELIUS G. FRIEDRICH, ${ }^{1 *}$ BÄRBEL FRIEDRICH ${ }^{2}$ AND \\ BOTHO BOWIEN ${ }^{1}$ \\ ${ }^{1}$ Institut für Mikrobiologie der Universität Göttingen and ${ }^{2}$ Institut für Mikrobiologie der \\ Gesellschaft für Strahlen- und Umweltforschung mbH, Grisebachstrasse 8, 3400 Göttingen, \\ Federal Republic of Germany
}

(Received 22 April 1980; revised 21 July 1980)

Alcaligenes eutrophus strain H16 formed key enzymes of autotrophic metabolism during heterotrophic growth. The formation of the soluble and membrane-bound hydrogenases, ribulose-5-phosphate kinase and ribulosebisphosphate carboxylase were investigated. In addition, selected enzymes shared by autotrophic and heterotrophic carbon metabolism were examined. Key enzymes of autotrophic metabolism were not detected during exponential growth on succinate, pyruvate or acetate, but were found at intermediate activities in cells grown on fructose, gluconate or citrate. Growth with succinate at a suboptimal $\mathrm{pH}$ of 7.7 resulted in a decreased growth rate and a marked increase of enzyme activities. Oxygen-limited growth with succinate also led to a derepression of the synthesis of the hydrogenases and the key enzymes of the Calvin cycle. During growth on glycerol or formate, the activities of these enzymes were comparable with those found under autotrophic conditions with $\mathrm{H}_{2}$ and $\mathrm{CO}_{2}$.

The results indicate that both the hydrogenases and the key enzymes of the Calvin cycle were formed under conditions of limited availability of energy. Molecular hydrogen was not required for the formation of the hydrogenases. The regulation of the gluconeogenetic enzymes, common to both autotrophic and heterotrophic carbon metabolism, was more balanced. An increase of enzyme activities was observed under autotrophic conditions, in accord with the physiological role of these enzymes under autotrophic and heterotrophic growth conditions.

\section{INTRODUCTION}

Alcaligenes eutrophus is an obligate aerobic, facultative chemolithoautotrophic microorganism. During autotrophic growth on carbon dioxide and hydrogen, the latter substrate is activated by a soluble $\mathrm{NAD}^{+}$-linked hydrogenase (EC 1.12.1.2) and a membrane-bound hydrogenase unable to reduce pyridine nucleotides. Carbon dioxide is fixed via the Calvin cycle; its initial reactions are catalysed by ribulose-5-phosphate kinase (EC 2.7.1.19) and ribulosebisphosphate carboxylase (EC 4.1.1.39).

There have been several reports on the appearance of the autotrophic key enzymes in hydrogen-oxidizing bacteria during heterotrophic growth. Schatz \& Bovell (1952) found 5 to $25 \%$ of the autotrophic hydrogen uptake rate with whole cells of Hydrogenomonas facilis grown on glucose, tryptose or lactate. This result could not be repeated by Wilson et al. (1953) who found complete repression of hydrogen uptake in cells grown heterotrophically on the above substrates. However, Wilson et al. (1953) reported that significant amounts of hydrogenase were present during growth on lactate provided the partial pressure of oxygen was reduced to $5 \%(5 \mathrm{kPa})$. Wilde (1962) applied these conditions to Alcaligenes eutrophus strain H16 (formerly Hydrogenomonas eutropha strain H16) but found no derepression of 
hydrogenase activity. However, she observed high hydrogenase activities in cells of $A$. eutrophus grown on glutamate, pyruvate, succinate, malate or acetate (Wilde, 1962). With pyruvate as carbon source a similar result was obtained by Schink \& Schlegel (1978). In contrast, Eberhardt (1966) did not find hydrogenase activity in succinate-grown cells, but he found intermediate activities in cells grown on fructose, as also reported by Rittenberg (1969) and Friedrich et al. (1979).

During growth of $A$. eutrophus on fructose, ribulosebisphosphate carboxylase was also present at intermediate activities, as reported by Kuehn \& McFadden (1968), Rittenberg (1969), and Stukus \& DeCicco (1970), but no activity was detected during growth on succinate (Rittenberg, 1969) or pyruvate (Stukus \& DeCicco, 1970).

To extend the limited knowledge on the formation of the key enzymes of the Calvin cycle and in view of the contradictory results concerning the formation of hydrogenase, we have re-examined the influence of growth conditions on the formation of key enzymes of autotrophic metabolism and selected enzymes of the central carbon metabolism. We have studied the effects of growth rate, aeration, time of harvest, treatment of the cells after harvest, and assay conditions of the enzymes. The present study defines the conditions under which the key enzymes of autotrophic metabolism are formed or are not formed. These results are a necessary basis for investigating the regulatory mechanisms that enable $A$. eutrophus to grow autotrophically.

\section{METHODS}

Organism. Alcaligenes eutrophus strain H16 (ATCC 17699, DSM 428) was used throughout this study.

Media and growth conditions. The medium of Schlegel et al. (1961) was used for precultures and cultures up to volumes of $300 \mathrm{ml}$ for autotrophic and heterotrophic growth in 11 baffled Erlenmeyer flasks. For enzyme studies, cells were precultivated in $10 \mathrm{ml}$ medium in $100 \mathrm{ml}$ Erlenmeyer flasks, then transferred to $250 \mathrm{ml}$ medium. When this culture reached about $1 \mathrm{~g}$ dry wt cells $1^{-1}$ it was used as inoculum for $10 \mathrm{l}$ medium in a 121 fermenter (B. Braun, Melsungen, F.R.G.). When cultures were grown autotrophically with $\mathrm{H}_{2}$ and $\mathrm{CO}_{2}$ or with organic acids, conditions were as described by Friedrich et al. (1979). With fructose or glycerol as carbon and energy source the extended culture technique was used in the following way. Acidification of the medium due to ammonia uptake was used to titrate a $1.0 \mathrm{M}-\mathrm{NaOH}$ solution containing $1.0 \mathrm{M}$-fructose or $1.76 \mathrm{M}$-glycerol. The ratio of carbon source to $\mathrm{NaOH}$ was based on the average nitrogen content of A. eutrophus $\left[17.6 \mathrm{~g} \mathrm{~N}\left(100 \mathrm{~g}\right.\right.$ dry wt cells) $\left.{ }^{-1}\right]$ and the yield coefficient of $Y_{\text {fructose }}=0.45$ and $Y_{\text {glycerol }}=0.50$. The fermenter was equipped with a steam sterilizable oxygen electrode (type G2L3; Biolafitte, Stuttgart, F.R.G.). The dissolved $\mathrm{O}_{2}$ partial pressure was recorded and not allowed to drop below $10 \mathrm{kPa}(0.1 \mathrm{~atm})$ during growth on organic substrates and was kept between 2 and $8 \mathrm{kPa}$ during autotrophic growth with $\mathrm{H}_{2}$ and $\mathrm{CO}_{2}$. The $\mathrm{O}_{2}$ content of the exit gas of the fermenter was determined with a paramagnetic $\mathrm{O}_{2}$ analyser (Magnos 2T; Hartmann \& Braun, Frankfurt, F.R.G.), and the exit $\mathrm{CO}_{2}$ concentration with an infrared analyser (Uras $7 \mathrm{~N}$ ). The results were recorded with a two-channel recorder.

Growth was followed turbidimetrically at $436 \mathrm{~nm}$. $\mathrm{O}_{2}$-limited growth was achieved by decreasing the $\mathrm{O}_{2}$ transfer rate by reducing the air flow rate from 4 to $1.51 \mathrm{~min}^{-1}$ and reducing the impeller rotation rate from 600 to $260 \mathrm{rev}$. $\min ^{-1}$.

The substrate shift from pyruvate to formate was done as described by Friedrich et al. (1979).

About $1 \mathrm{~g}$ wet wt cells was needed to obtain sufficient quantities of particulate hydrogenase and the membrane-bound cytochromes. Samples of 100 to $300 \mathrm{ml}$ culture were taken and immediately cooled to $0{ }^{\circ} \mathrm{C}$; the bacteria were collected by centrifugation (Christ Junior 2, Osterode/Harz, F.R.G.) for $15 \mathrm{~min}$ at $5000 \mathrm{rev}$. $\mathrm{min}^{-1}$, washed once with ice-cold $0.9 \%(\mathrm{w} / \mathrm{v}) \mathrm{NaCl}$ and stored frozen at $-20^{\circ} \mathrm{C}$. Cell-free extracts and membrane fractions were prepared at $0^{\circ} \mathrm{C}$ according to the procedure described by Friedrich et al. (1979).

Enzyme assays. Enzyme activities were determined at $30^{\circ} \mathrm{C}$ and expressed as units (mg protein) $)^{-1}$. One unit (U) of enzyme activity was defined as the utilization of $1 \mu \mathrm{mol}$ substrate $\mathrm{min}^{-1}$. The soluble hydrogenase (hydrogen: $\mathrm{NAD}^{+}$oxidoreductase; EC 1.12.1.2), particulate hydrogenase and ribulose-5-phosphate kinase (EC 2.7.1.19) activities were determined as described by Friedrich et al. (1979). Ribulosebisphosphate carboxylase (EC 4.1.1.39) activity was measured by ribulose bisphosphate-dependent incorporation of ${ }^{14} \mathrm{CO}_{2}$ into acid-stable product as described by Bowien et al. (1976). The following enzyme activities were measured spectrophotometrically at $340 \mathrm{~nm}$. Fructose-1,6-bisphosphatase (EC 3.1.3.11) was assayed according to Abdelal \& Schlegel (1974). Fructose-1,6-bisphosphate aldolase (EC 4.1.2.13) was determined in a reaction mixture containing (total vol. $0.60 \mathrm{ml}) 50 \mathrm{mM}$-Tris/ $\mathrm{HCl}$ buffer $(\mathrm{pH} 7.6), 1 \mathrm{~mm}-\mathrm{Fe}\left(\mathrm{NH}_{4}\right)_{2} \mathrm{SO}_{4}, 1 \mathrm{~mm}$-cysteine hydro- 
chloride, $1 \mathrm{U}$ glycerol-3-phosphate dehydrogenase (EC 1.1.1.8), $3 \mathrm{U}$ triosephosphate isomerase (EC 5.3.1.1), $0.25 \mathrm{~mm}-\mathrm{NADH}, 2 \mathrm{~mm}$-fructose-1,6-bisphosphate and an appropriate amount of enzyme. Assay mixtures were incubated anaerobically by sparging the cuvettes with pure nitrogen, thus avoiding the oxidation of ferrous iron. 3-Phosphoglycerate kinase (EC 2.7.2.3) was assayed in a mixture containing (total vol. $1.0 \mathrm{ml}) 80 \mathrm{~mm}$ Tris/ $\mathrm{HCl}$ buffer ( $\mathrm{pH} 7.4), 5.5 \mathrm{~mm}-\mathrm{MgSO}_{4}, 0.4 \mathrm{mM}$-EDTA, $10 \mathrm{U}$ glyceraldehyde-3-phosphate dehydrogenase (EC 1.2.1.12), 0.25 mM-NADH, 2.5 mM-ATP, $8 \mathrm{~mm}$-3-phosphoglycerate and enzyme. Glyceraldehyde3-phosphate dehydrogenase activity was determined in an identical system except that $10 \mathrm{U} 3$-phosphoglycerate kinase was added instead of glyceraldehyde-3-phosphate dehydrogenase.

Cytochrome identification. Quantitative determination of membrane-bound cytochromes $a a_{3}, b$ and $c$ as well as soluble cytochrome $c$ was done as described by Probst \& Schlegel (1976). The soluble flavohaemoprotein was determined as described by Probst et al. (1979).

Immunochemical analysis. Antisera against purified ribulosebisphosphate carboxylase and soluble hydrogenase were prepared as previously described (Bowien \& Mayer, 1978; Schink \& Schlegel, 1980). The presence of ribulosebisphosphate carboxylase and hydrogenase antigen in cell extracts was determined by immunodiffusion according to Ouchterlony (1953).

Protein was determined by the Lowry method.

\section{RESULTS}

\section{Enzyme activities during different growth phases in batch culture}

The activities of enzymes of autotrophic metabolism in Alcaligenes eutrophus were followed during autotrophic and heterotrophic growth in batch culture. Ammonia was chosen to restrict the final amount of growth in order to allow conditions comparable to those of autotrophic growth where the gaseous substrates have to be continuously transferred to the medium. In order to supply the substrate continuously to heterotrophically grown cultures the extended culture technique was chosen to keep the organic substrate concentration relatively constant. Growth ceased at about $3 \mathrm{~g}$ dry wt cells $1^{-1}$ due to complete exhaustion of ammonia in the medium. The surplus of the carbon source, however, allowed an increase in cell mass due to the formation of intracellular poly- $\beta$-hydroxybutyrate (results not shown).

Figure 1 shows the growth of $A$. eutrophus with glycerol as carbon and energy source and the enzyme activities determined. It is evident that in this heterotrophic culture both the

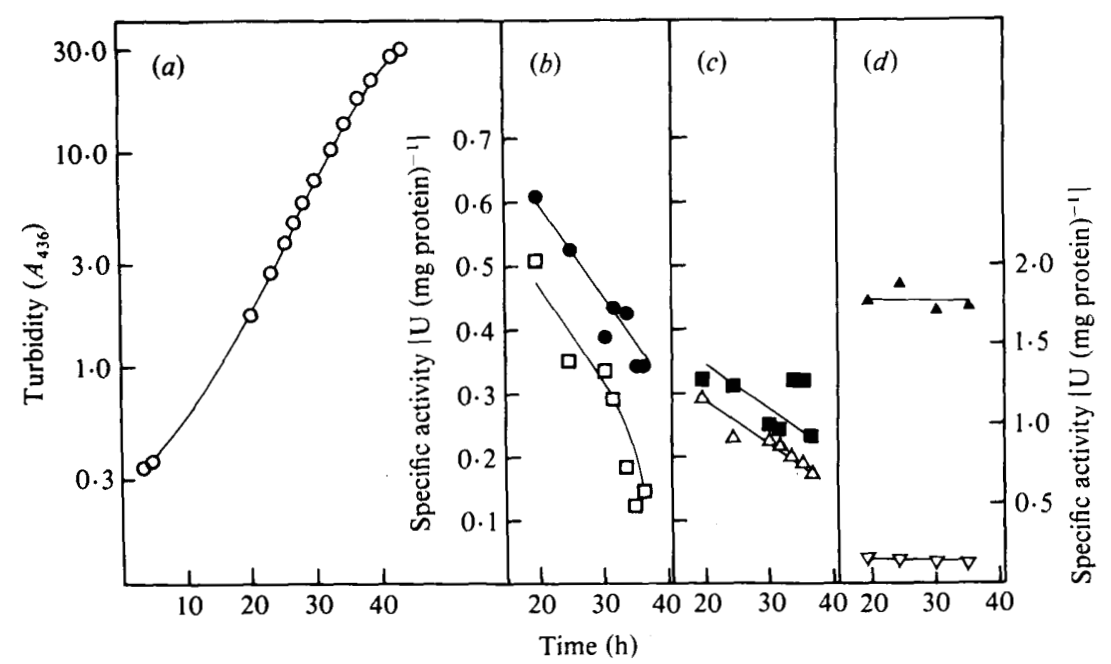

Fig. 1. Enzyme activities during growth of Alcaligenes eutrophus on glycerol. Cells were grown in a 121 fermenter (see Methods) with $0.2 \%(\mathrm{w} / \mathrm{v}) \mathrm{NH}_{4} \mathrm{Cl}$ and $0.5 \%(\mathrm{w} / \mathrm{v})$ glycerol. Glycerol was added continuously according to growth and consumption. Appropriate culture samples were taken to yield about $1 \mathrm{~g}$ wet wt and processed as described in Methods. Turbidity (O), soluble hydrogenase (O), membrane-bound hydrogenase $(\square)$, ribulose-5-phosphate kinase ( $\square$ ), ribulosebisphosphate carboxylase $(\Delta)$, glyceraldehyde-3-phosphate dehydrogenase $(\Delta)$, fructose-1,6-bisphosphate aldolase $(\nabla)$. 
Table 1. Specific activities of enzymes of autotrophic metabolism of Alcaligenes eutrophus grown on various carbon sources

$\begin{array}{lccccc}\begin{array}{c}\text { Carbon } \\ \text { source }\end{array} & \begin{array}{c}\text { Specific } \\ \text { growth rate } \\ \left(\mathrm{h}^{-1}\right)\end{array} & \overbrace{\text { Soluble }}^{\text {Hydrogenase }} & \text { Particulate } & \begin{array}{c}\text { Ribulose- } \\ \text { 5-phosphate } \\ \text { kinase }\end{array} & \begin{array}{c}\text { Specific activity [U } \\ \text { bisphosphate } \\ \text { carboxylase }\end{array} \\ \mathrm{CO}_{2} / \mathrm{H}_{2} & 0.22 & 0.916 & 0.387 & 0.210 & 0.258 \\ \text { Formate } & 0.17 & 0.480 & 0.343 & 0.268 & 0.264 \\ \text { Glycerol } & 0.14 & 0.518 & 0.290 & 0.242 & 0.216 \\ \text { Fructose } & 0.33 & 0.190 & 0.065 & 0.045 & 0.036 \\ \text { Gluconate } & 0.33 & 0.189 & 0.047 & 0.017 & 0.061 \\ \text { Citrate } & 0.38 & 0.068 & 0.005 & 0.034 & 0.026 \\ \text { Pyruvate } & 0.46 & 0.015 & 0.005 & 0.001 & 0.001 \\ \text { Succinate } & 0.46 & 0.010 & 0.002 & 0.001 & 0.003 \\ \text { Acetate } & 0.46 & 0.005 & 0.002 & 0.001 & 0.001\end{array}$

soluble $\mathrm{NAD}^{+}$-linked and the membrane-bound hydrogenases were produced at activities up to $0.6 \mathrm{U}$ (mg protein) $)^{-1}$ (Fig. $1 \mathrm{~b}$ ), which were similar to the activities found in autotrophically grown bacteria. However, the specific activity of the hydrogenase did not remain constant during the exponential growth phase but decreased gradually. A similar decrease of both hydrogenase activities was observed during autotrophic growth with $\mathrm{H}_{2}$ and $\mathrm{CO}_{2}$ but not during heterotrophic growth with fructose.

The activities of ribulose-5-phosphate kinase and ribulosebisphosphate carboxylase (Fig. 1c) were similar to those found in bacteria grown autotrophically with either $\mathrm{H}_{2}$ and $\mathrm{CO}_{2}$ or formate as carbon and energy source (Friedrich et al., 1979). Again, there was a slight decrease in activity as the bacterial mass increased with time. Ribulosebisphosphate carboxylase was not rapidly inactivated when the culture reached the stationary growth phase caused by depletion of ammonia from the medium. Kuehn \& McFadden (1968) reported a rapid inactivation of the enzyme when the carbon source fructose was exhausted. Activities of representative enzymes of gluconeogenesis and glycolysis - fructose-1,6-bisphosphate aldolase and glyceraldehyde-3-phosphate dehydrogenase - did not vary significantly during growth (Fig. 1d). This was also observed when cells were grown autotrophically with $\mathrm{H}_{2}$ and $\mathrm{CO}_{2}$ or heterotrophically with fructose or pyruvate.

For further investigations, bacteria were harvested in the mid-exponential growth phase when the biomass was approximately $1 \mathrm{~g}$ dry wt cells $1^{-1}$. This enabled a comparison to be made between the enzyme activities with different carbon and energy sources.

\section{Enzyme activities during growth on different substrates}

During heterotrophic growth the key enzymes of autotrophic metabolism exhibited specific activities which depended on the carbon substrate (Table 1). On glycerol the enzyme activities were as high as those found when cultures were grown autotrophically with $\mathrm{H}_{2}$ and $\mathrm{CO}_{2}$. Alcaligenes eutrophus also grows autotrophically with formate where ribulose-5-phosphate kinase and ribulosebisphosphate carboxylase are essential for growth, but the hydrogenases are not. The latter enzymes, however, were present at high activities during growth on formate (Table 1) (see also Friedrich et al., 1979).

On substrates such as fructose, gluconate or citrate, only low activities of the hydrogenases were observed. With succinate, pyruvate or acetate only trace activities of the key enzymes of autotrophic metabolism were detected.

\section{Effect of growth rate}

The growth rates and activities of the key enzymes of autotrophic metabolism during growth on different substrates are listed in Table 1. The activities of the enzymes were 
Table 2. Specific activities of enzymes of autotrophic metabolism during optimal and suboptimal growth of Alcaligenes eutrophus

Alcaligenes eutrophus was grown in a 121 fermenter and samples were taken during exponential growth and processed as described in Methods.

\begin{tabular}{|c|c|c|c|c|c|c|c|}
\hline \multirow{2}{*}{\multicolumn{3}{|c|}{ Growth conditions }} & \multirow{3}{*}{$\begin{array}{c}\text { Specific } \\
\text { growth rate } \\
\left(\mathrm{h}^{-1}\right)\end{array}$} & \multicolumn{4}{|c|}{ Specific activity [U (mg protein $\left.)^{-1}\right]$} \\
\hline & & & & \multicolumn{2}{|c|}{ Hydrogenase } & \multirow{2}{*}{$\begin{array}{l}\text { Ribulose- } \\
\text { 5-phosphate } \\
\text { kinase }\end{array}$} & \multirow{2}{*}{$\begin{array}{l}\text { Ribulose- } \\
\text { bisphosphate } \\
\text { carboxylase }\end{array}$} \\
\hline $\begin{array}{l}\text { Carbon } \\
\text { source }\end{array}$ & $\begin{array}{l}\text { Temp. } \\
\left({ }^{\circ} \mathrm{C}\right)\end{array}$ & $\mathrm{pH}$ & & Soluble & $\overbrace{\text { Particulate }}^{0}$ & & \\
\hline Succinate & 30 & $7 \cdot 0$ & 0.46 & 0.005 & 0.005 & 0.002 & 0.003 \\
\hline Succinate & 17 & $7 \cdot 0$ & $0 \cdot 15$ & 0.044 & 0.002 & 0.002 & 0.001 \\
\hline Succinate & 30 & $7 \cdot 7$ & 0.07 & 0.612 & 0.002 & 0.082 & 0.058 \\
\hline Fructose & 30 & 7.0 & 0.32 & 0.108 & 0.030 & 0.077 & 0.041 \\
\hline Fructose & 30 & $7 \cdot 7$ & 0.13 & 0.124 & 0.004 & 0.022 & 0.017 \\
\hline
\end{tabular}

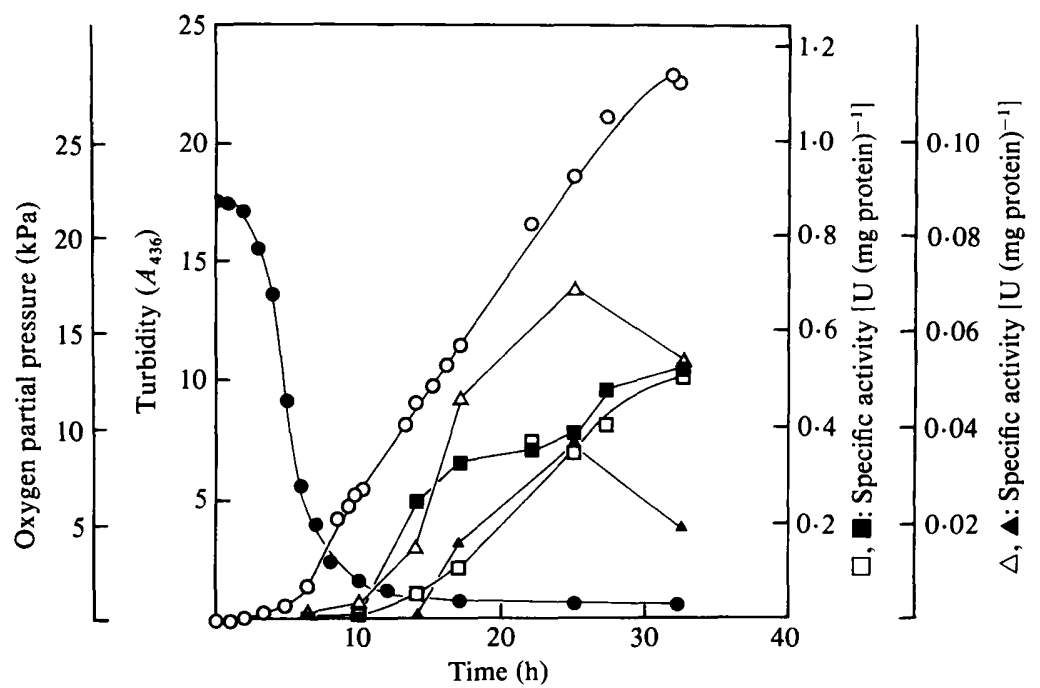

Fig. 2. Enzyme activities of Alcaligenes eutrophus during oxygen-limited growth on succinate. Turbidity $(O)$, oxygen partial pressure (O), membrane-bound hydrogenase ( $\square$ ), soluble hydrogenase (D), ribulosebisphosphate carboxylase $(\triangle)$, ribulose-5-phosphate kinase $(\Delta)$.

apparently inversely correlated with the growth rates. In order to distinguish between a substrate-specific and a growth rate-specific effect, two substrates were chosen and the growth rates were decreased by applying suboptimal growth conditions.

Alcaligenes eutrophus was grown with succinate as carbon source at $17^{\circ} \mathrm{C}$ giving a specific growth rate of $0.15 \mathrm{~h}^{-1}$ compared with $0.46 \mathrm{~h}^{-1}$ at $30^{\circ} \mathrm{C}$. At $17^{\circ} \mathrm{C}$ the hydrogenase activity was 5 to $7 \%$ of that of autotrophically grown cells (Table 2). In a different experiment at $30^{\circ} \mathrm{C}$, at a constant $\mathrm{pH}$ of 7.7 , the specific growth rate was $0.07 \mathrm{~h}^{-1}$. Under these conditions, the soluble hydrogenase was present at a high activity and the key enzymes of the Calvin cycle were found at intermediate activity.

Since a heterotrophic substrate supplies the cell with carbon and energy it was of interest to know if the decrease in growth rate and the concomitant increase in activities of the key enzymes of autotrophic metabolism were due to carbon or energy limitation. Energy limitation can be achieved by limiting the supply of either the electron donor or the electron acceptor. Under heterotrophic growth conditions the choice was restricted to the limitation of the electron acceptor - oxygen. Figure 2 shows the growth of $A$. eutrophus on succinate in extended culture with oxygen as the growth-limiting substrate. Under this condition, the 


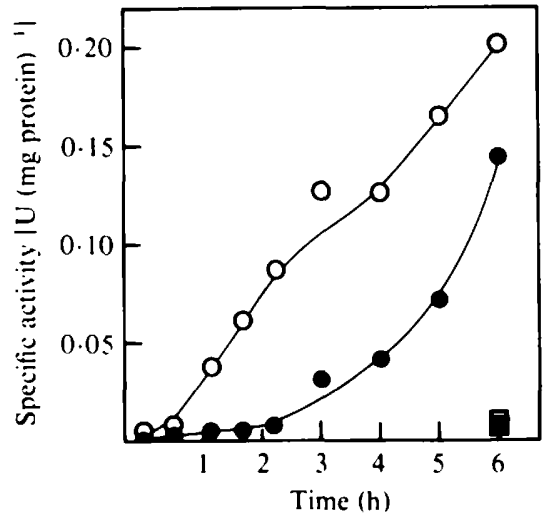

Fig. 3. Rate of formation of the key enzymes of autotrophic metabolism after a substrate shift from pyruvate to formate. The substrate shift and determination of enzyme activity were done as described in Methods. Formate was added at zero time. Ribulosebisphosphate carboxylase $(O)$, soluble hydrogenase (O), ribulosebisphosphate carboxylase in the presence of $200 \mu \mathrm{g}$ chloramphenicol $\mathrm{ml}^{-1}(\square)$, soluble hydrogenase in the presence of $200 \mu \mathrm{g}$ chloramphenicol $\mathrm{ml}^{-1}(\mathbb{\square})$.

culture did not grow exponentially but arithmetically because of the constant oxygen transfer rate within the fermenter; thus the specific growth rate continuously decreased. After the onset of oxygen limitation, the activity of the soluble hydrogenase significantly increased as, after a short delay, did the activity of the particulate hydrogenase. Both enzymes reached similar activities to those in autotrophically grown cells within the duration of the experiment. Ribulose-5-phosphate kinase and ribulosebisphosphate carboxylase were also produced, but at only $30 \%$ of the activity in autotrophically grown cells.

\section{Coordination of enzymes of autotrophic energy and carbon metabolism}

As has been shown before (Friedrich et al., 1979), ribulose-5-phosphate kinase and ribulosebisphosphate carboxylase appeared to be synthesized coordinately. Neither enzyme was present in pyruvate-grown cells (Table 1).

The appearance of the energy-generating and carbon-assimilating enzymes during oxygen-limited growth indicated that the formation of the hydrogenases and the carbon dioxide-assimilating enzymes was not strictly coordinate (Fig. 2). The activities of two indicator enzymes of autotrophic metabolism - ribulosebisphosphate carboxylase and the soluble hydrogenase - were therefore followed in a transition experiment. Pyruvate-grown cells were shifted down to formate as sole source of carbon and energy (Fig. 3). Only $30 \mathrm{~min}$ after the addition of formate to the medium, ribulosebisphosphate carboxylase activity was detected and thereafter increased at a constant rate. The soluble hydrogenase was formed after a lag of more than $2 \mathrm{~h}$. This result was further support for the non-coordinate control of the carbon-assimilating and energy-generating enzymes.

\section{Immunochemical analysis of enzyme formation}

Double immunodiffusion assays were performed with crude extracts from cells grown on succinate, pyruvate, fructose and glycerol or under autotrophic conditions with $\mathrm{H}_{2}$ and $\mathrm{CO}_{2}$. Antisera against two representative enzymes of autotrophic metabolism - ribulosebisphosphate carboxylase and the soluble NAD+-linked hydrogenase - showed crossreactions with cell extracts except those derived from cells grown on succinate or pyruvate. Thus. the enzyme activities determined truly reflect the presence or absence of the two indicator proteins. 
Table 3. Specific activities of some gluconeogenetic enzymes of Alcaligenes eutrophus grown on various carbon sources

Growth conditions and extract preparations were identical to those of Table 1.

\begin{tabular}{lcccc} 
& \multicolumn{4}{c}{ Specific activity [U (mg protein) ${ }^{-1}$ ] } \\
\cline { 2 - 3 } $\begin{array}{c}\text { Carbene-1,6- } \\
\text { source }\end{array}$ & $\begin{array}{c}\text { Fructose-1,6- } \\
\text { bisphosphate } \\
\text { bisphosphatase } \\
\text { aldolase }\end{array}$ & $\begin{array}{c}\text { Glyceraldehyde- } \\
\text { 3-phosphate } \\
\text { dehydrogenase }\end{array}$ & $\begin{array}{c}\text { 3-Phospho- } \\
\text { glycerate } \\
\text { kinase }\end{array}$ \\
$\mathrm{CO}_{2} / \mathrm{H}_{2}$ & 0.268 & 0.172 & 2.43 & 1.36 \\
Formate & 0.186 & 0.201 & 1.20 & 1.19 \\
Glycerol & 0.177 & 0.198 & 2.54 & 1.87 \\
Fructose & 0.154 & 0.175 & 1.77 & 1.37 \\
Citrate & 0.032 & 0.113 & 0.755 & 0.824 \\
Pyruvate & 0.051 & 0.177 & 1.74 & 1.31 \\
Succinate & 0.059 & 0.114 & 0.649 & 0.788
\end{tabular}

\section{Activities of selected enzymes of the central carbon metabolism}

Fructose-1,6-bisphosphatase, fructose-1,6-bisphosphate aldolase, glyceraldehyde-3phosphate dehydrogenase and 3-phosphoglycerate kinase function in the Calvin cycle during autotrophic growth and also in the gluconeogenetic and glycolytic pathways during heterotrophic growth. Therefore, the influence of different substrates on the activities of these enzymes was examined (Table 3). Although the magnitude of the variations in their activities was not as pronounced as observed for the enzymes of autotrophic metabolism, the overall pattern was similar (Table 1). The enzymes showed highest activities during autotrophic growth with $\mathrm{H}_{2}$ and $\mathrm{CO}_{2}$ or heterotrophic growth with glycerol. With formate, fructose, gluconate or pyruvate the enzymes were also present at a relatively high activity. Bacteria grown on succinate, acetate or citrate showed significantly lower activities, probably representing the basal activity of the enzymes. Although there was some variation in the enzyme activities in different experiments, the results for individual experiments always exhibited the activity pattern described above. This is compatible with the different physiological role of these enzymes under autotrophic and heterotrophic growth conditions. While all carbon must flow through these essential Calvin cycle activities during autotrophic growth, only that fraction of carbon necessary for cell wall synthesis has to pass this route in cells growing heterotrophically on gluconeogenetic substrates, such as succinate. It has recently been shown that the gluconeogenetic carbon requirement of Escherichia coli is about $5 \%$ of its total catabolic and anabolic needs (Irani \& Maitra, 1977).

\section{Cytochrome content}

No qualitative difference was found in either the membrane-bound cytochromes $a a_{3}, b$ or $c$ or the cytoplasmic cytochrome $c$ or the oxygen-binding flavohaemoprotein in cells grown under autotrophic or heterotrophic conditions, thus confirming the results of Probst \& Schlegel (1976). There was also no significant quantitative difference in the content of membrane-bound cytochromes under the different growth conditions (results not shown). The concentration of soluble flavohaemoprotein, however, was about fivefold higher in autotrophically grown cells than in those grown heterotrophically (Table 4). The reason for this observation is not known. It was suggested (Probst et al., 1979) that the soluble flavohaemoprotein, because of its high affinity to oxygen, functions as an oxygen store providing a constant oxygen tension to the cell. In fact, during autotrophic growth either with formate or $\mathrm{H}_{2}$ and $\mathrm{CO}_{2}$ the oxygen demand is about six- to eightfold higher than during heterotrophic growth on, for example, fructose or pyruvate. 


\section{Table 4. Cytoplasmic cytochrome content of Alcaligenes eutrophus grown on various carbon sources}

Cytochrome $c$ was identified and quantified as described by Probst \& Schlegel (1976) and flavohaemoprotein as described by Probst et al. (1979).

$\begin{array}{lcc}\begin{array}{c}\text { Carbon } \\ \text { source }\end{array} & \begin{array}{c}\text { Cytochrome content } \\ {\left[\mu \mathrm{mol}(\mathrm{g} \text { protein })^{-1}\right]}\end{array} \\ \mathrm{CO}_{2} / \mathrm{H}_{2} & 0.035 & 0.270 \\ \text { Flavohaemoprotein } & \text { Cytochrome } c \\ \text { Pyruvate } & 0.038 & 0.145 \\ \text { Fructose } & 0.009 & 0.152 \\ & 0.006 & 0.150\end{array}$

\section{DISCUSSION}

The results presented in this paper provide evidence that Alcaligenes eutrophus strain H16 produces the key enzymes of autotrophic energy generation and $\mathrm{CO}_{2}$ fixation during growth on different organic substrates. Three groups of substrates could be distinguished: (i) with formate or glycerol these enzymes were formed at activities comparable with those found under autotrophic growth conditions with $\mathrm{H}_{2}$ and $\mathrm{CO}_{2}$ as sources of energy and carbon; (ii) fructose, gluconate or citrate allowed the production of intermediate enzyme activities up to $20 \%$ of the autotrophic values; (iii) during growth on pyruvate, succinate or acetate the formation of the enzymes was completely repressed. These results are in accord with those of a previous study (Stukus \& DeCicco, 1970) with the A. eutrophus type strain, which demonstrated the total repression of ribulosebisphosphate carboxylase by pyruvate or acetate and a partial repression of this enzyme by fructose or glutamate. The fact that the soluble as well as the membrane-bound hydrogenase was present in heterotrophically grown cells suggested that the synthesis of these enzymes was regulated by a repression/derepression mechanism at the transcriptional level. Since no $\mathrm{H}_{2}$ was produced heterotrophically under the experimental conditions employed (unpublished result), molecular hydrogen is not considered as an inducer of the hydrogenase system. At present, no conclusion can be drawn regarding the regulation of the $\mathrm{CO}_{2}$-fixing system. $\mathrm{CO}_{2}$ cannot be excluded as inducer since it is always present in the cell. However, repression/derepression has been suggested as a control mechanism for the synthesis of ribulosebisphosphate carboxylase in Pseudomonas oxalaticus (Dijkhuizen \& Harder, 1979).

The growth rate supported by a particular substrate depends on its quality either as carbon or as energy source. For $A$. eutrophus there was an inverse relationship between the specific growth rate on different substrates and the specific activity of the key enzymes of autotrophic metabolism. The substrates which supported fast growth - pyruvate, succinate or acetate exerted a severe repression on the synthesis of these enzymes. These results resemble those reported for $P$. oxalaticus whose $\mathrm{CO}_{2}$-fixing enzyme system is also repressed by substrates that support fast growth (Blackmore et al., 1968; Dijkhuizen et al., 1978). However, our results indicate that the autotrophic enzymes of $A$. eutrophus are not simply formed in response to the growth rate. A decrease in the growth rate on succinate caused by a decrease in temperature to $17^{\circ} \mathrm{C}$, or on fructose at $\mathrm{pH} 7 \cdot 7$, did not result in high enzyme activities. On the other hand, a decrease in the growth rate on succinate caused by limitation of the electron acceptor oxygen led to the formation of the autotrophic enzymes, as did growth on succinate at $\mathrm{pH} 7.7$ when the rate of uptake of this substrate was presumably restricted. Therefore, a limited supply of energy rather than of carbon appears to be responsible for the formation of the key enzymes of autotrophic metabolism in A. eutrophus. This conclusion is consistent with earlier observations of Kuehn \& McFadden (1968) who found that ribulosebisphosphate carboxylase was present at high concentrations in cells of the A. eutrophus type 
strain and Pseudomonas facilis grown on fructose with a low aeration rate. Furthermore, hydrogen uptake was markedly increased in $P$. facilis grown on lactate under oxygen starvation (Wilson et al., 1953).

The physiological and enzymic results indicate an apparent correlation between the formation of enzymes of $\mathrm{H}_{2}$ oxidation and $\mathrm{CO}_{2}$ assimilation. However, since nothing is known about their genetic interrelationship it is too early to speculate about a coordination of enzyme synthesis on a molecular basis. Further studies with mutants altered in the regulation of the respective enzymes should elucidate this question.

The immunochemical analysis showed that the various activities of the autotrophic enzymes correlated with the respective enzyme proteins present in the cells. In addition, substrate shift-down experiments from pyruvate to formate in the presence of chloramphenicol confirmed the assumption that new protein synthesis is primarily involved in the regulation of the autotrophic enzymes. Similarly, Rittenberg (1969) found that the $A$. eutrophus type strain showed a marked increase in specific activity of hydrogenase at the end of the exponential growth phase when cultured on a variety of organic substrates. The increase was not observed if cultures were treated with chloramphenicol before reaching the stationary phase.

We thank Dr I. Probst for the determination of the cytochromes and Ms A. Finck, G. Mitrenga and P. Schobert for their skilful technical assistance during part of this work.

\section{REFERENCES}

Abdelal, A. T. \& Schlegel, H. G. (1974). Purification and regulatory properties of fructose 1,6diphosphatase from Hydrogenomonas eutropha. Journal of Bacteriology 120, 304-310.

Blackmore, M. A., QUAYLE, J. R. \& WALKer, J. O. (1968). Choice between autotrophy and heterotrophy in Pseudomonas oxalaticus: utilization of oxalate by cells after adaptation from growth on formate to growth on oxalate. Biochemical Journal 107, 699-704.

Bowien, B. \& MAYER, F. (1978). Further studies on the quaternary structure of D-ribulose-1,5bisphosphate carboxylase from Alcaligenes eutrophus. European Journal of Biochemistry 88, 97-107.

Bowien, B., Mayer, F., Codd, G. A. \& Schlegel, H. G. (1976). Purification, some properties and quaternary structure of the D-ribulose 1,5-diphosphate carboxylase of Alcaligenes eutrophus. Archives of Microbiology 110, 157-166.

DiJkHuizen, L. \& HARder, W. (1979). Regulation of autotrophic and heterotrophic metabolism in Pseudomonas oxalaticus OX1: growth on mixtures of acetate and formate in continuous culture. Archives of Microbiology 123, 47-53.

DiJkhuizen, L., KNIGHT, M. \& HARDER, W. (1978). Metabolic regulation in Pseudomonas oxalaticus OX1. Autotrophic and heterotrophic growth on mixed substrates. Archives of Microbiology 116, 77-83.

EBERHARDT, U. (1966). Über das Wasserstoff aktivierende System von Hydrogenomonas H16. II. Abnahme der Aktivitäten bei heterotrophem Wachstum. Archiv für Mikrobiologie 54, 115-124.
Friedrich, C. G., Bowien, B. \& FrIedrich, B. (1979). Formate and oxalate metabolism in Alcaligenes eutrophus. Journal of General Microbiology 115, 185-192.

Irani, M. H. \& Martra, P. K. (1977). Properties of Escherichia coli mutants deficient in enzymes of glycolysis. Journal of Bacteriology 132, 398-410.

KUEHN, G. D. \& MCFADDEN, B. A. (1968). Enzymes of the Entner-Doudoroff pathway in fructose-grown Hydrogenomonas eutropha. Canadian Journal of Microbiology 14, 1259-1260.

OUCHTERLONY, Ö. (1953). Antigen-antibody reactions in gels; types of reaction in coordinated systems of diffusion. Acta pathologica et microbiologica scandinavica 32, 231-240.

Probst, I. \& Schlegel, H. G. (1976). Respiratory components and oxidase activities in Alcaligenes eutrophus. Biochimica et biophysica acta 440, 412-428.

Probst, I., Wolf, G. \& Schlegel, H. G. (1979). An oxygen-binding flavohemoprotein from Alcaligenes eutrophus. Biochimica et biophysica acta 576, 471-478.

RITTENBERG, S. C. (1969). The roles of exogenous organic matter on the physiology of chemolithotrophic bacteria. Advances in Microbial Physiology 3, 159-196.

Schatz, A. \& Bovell, C. (1952). Growth and hydrogenase activity of a new bacterium, Hydrogenomonas facilis. Journal of Bacteriology 63, 87-98.

SchiNK, B. \& Schlegel, H. G. (1978). Mutants of Alcaligenes eutrophus defective in autotrophic 
metabolism. Archives of Microbiology 117, 123129.

SchiNk, B. \& Schlegel, H. G. (1980). The membrane-bound hydrogenase of Alcaligenes eutrophus. II. Localization and immunological comparison to other hydrogenase systems. Antonie van Leeuwenhoek 46, 1-14.

Schlegel, H. G., Kaltwasser, H. \& Gottschalk, G. (1961). Ein Submersverfahren zur Kultur wasserstoffoxidierender Bakterien: Wachstumsphysiologische Untersuchungen. Archiv für Mikrobiologie 38, 209-222.
Stukus, P. E. \& DeCicco, B. T. (1970). Autotrophic and heterotrophic metabolism of Hydrogenomonas: regulation of autotrophic growth by organic substrates. Journal of Bacteriology 101, 339-345.

WILDE, E. (1962). Untersuchungen über Wachstum und Speicherstoffsynthese von Hydrogenomonas. Archiv für Mikrobiologie 43, 109-137.

Wilson, E., Stout, H. A., Powelson, D. \& Koffler, H. (1953). Comparative biochemistry of the hydrogen bacteria. I. The simultaneous oxidation of hydrogen and lactate. Journal of Bacteriology 65, 283-287. 